УДК 629.4.027.2:629.45

Д-р техн. наук І.Е. Мартинов (УкрДАЗТ), асп. В.В. Ільчищин (ДП УкрНДІВ), інж. О.С. Калмиков, магістрант М.В. Троцька (УкрДАЗТ)

\title{
ДОСЛІДЖЕННЯ ДИНАМІЧНИХ НАВАНТАЖЕНЬ, ЩО ДІЮТЬ НА ВІЗКИ ПАСАЖИРСЬКИХ ВАГОНІВ НОВОГО ПОКОЛІННЯ
}

Постановка проблеми у загальному вигляді, іiї зв'язок 3 важливими науковими та практичними завданнями. Парк пасажирських вагонів України складається 3 різноманіття типів і моделей вагонів, які будувалися, головним чином, ще за часів СРСР. Переважна більшість пасажирських вагонів вже проходила технічне обстеження 3 призначенням відповідного ремонту та продовженням терміну експлуатації. Тобто рухомий склад безупинно старіє, а його ресурс практично вичерпаний. Це позначається не лише на збільшенні обсягу робіт 3 ремонту та технічного обслуговування вагонів, але і на рівні безпеки руху. В умовах жорсткої конкуренції на ринку транспортних послуг залізницям зараз вже недостатньо мати просто пасажирські вагони збільшеної місткості. Вагони нового покоління 
повинні мати не лише підвищену надійність, але й поліпшені комфортні умови для пасажирів. Фактором підвищення комфортності поїздки, а також збільшення надійності та терміну служби вагонів $є$ зменшення величин динамічних сил, що виникають від взаємодії коліс 3 рейками. Як відомо, поліпшення динамічних показників вагонів та плавності руху можна досягти за рахунок застосування візків із збільшеним статичним прогином ресорного підвішування та зниження рівня збурення колії.

Аналіз останніх досліджень i публікацій. ПАТ "Крюківський вагонобудівний завод"останніми роками активно працює у галузі створення пасажирських вагонів нового покоління, в тому числі призначених для швидкісного руху.

Але розрахунок показників міцності та надійності виконується добре відомими методами згідно $3[1,2]$. Навантаження, що діють на вагони та їх елементи, вважаються постійними. Наявність динамічної складової як у вертикальних, так i горизонтальних навантаженнях враховується шляхом використання відповідно коефіцієнта вертикальної та горизонтальної динаміки. Ці коефіцієнти мають емпіричний характер. Поза увагою дослідників залишилося те, що навантаження, які діють на візки, мають випадковий характер та являють собою випадковий процес.

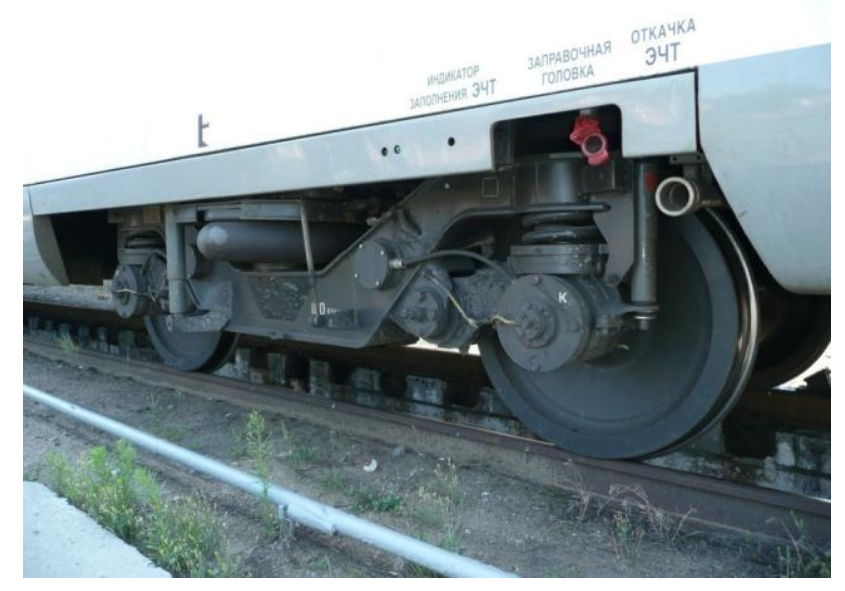

Рис. 1. Загальний вигляд візка моделі 68-7041
Метою дослідження $\epsilon$ визначення законів розподілення динамічних навантажень, що діють на візки пасажирських вагонів 3 пневматичним підвішуванням.

Основна частина. Візки немоторні 3 пневматичним підвішуванням моделей 687041 в залежності від варіанта виконання призначені для підкочування під пасажирські вагони моделей 61-779Э, 61788 та їх модифікацій, що експлуатуються на залізницях колії 1520 мм та рухаються 3 конструкційною швидкістю до 160 км/год. Вони також використовуються у пасажирських вагонах денних швидкісних поїздів локомотивної тяги міжрегіонального сполучення, а також у причіпних вагонах двосистемного електропоїзда міжрегіонального сполучення.

Візки двовісні безколискового типу і складаються 3 рами, надресорної балки, двох колісних пар, надбуксового (первинного) ресорного підвішування, центрального (вторинного) ресорного пневматичного підвішування, гідравлічних гасників коливань (чотири буксових вертикальних, два центральних вертикальних та один горизонтальний), елементів протиюзових пристроїв, гальмівної системи, вузлів з'єднання букси колісної пари 3 рамою візка, стабілізатора бокового хитання та вузлів з'єднання кузова з візком (рис. 1). 
Рама візка жорсткого типу має моноблочну штампозварну конструкцію, включає дві поздовжні балки, зварені 3 гнутого листового прокату та з'єднані між собою двома поперечними балками круглого перерізу. Поперечні балки рами оснащені кронштейнами підвішування гальмівних блоків, кронштейнами кріплення центральної рамки вузла 3'єднання кузова вагона 3 візком та кронштейнами для встановлення тяг механізму поздовжнього привода візка. Поздовжні балки облаштовані кронштейнами для установлення важелів 3'єднання букс колісної пари 3 рамою, кронштейнами для стабілізатора бокового хитання, гасників коливань, кронштейнами кріплення упорів від повороту візка (для візків виконання 06 та 07), кронштейнами для піднімання рами та візка в цілому, опорними місцями для пружин буксового підвішування та місцями кріплення пневматичних ресор фірми CONTITECH.

Надресорна балка зварної конструкції iз сталевих листів та гнутих елементів опора для пневматичних ресор центрального ресорного підвішування, забезпечує надійний підвід повітря для живлення пневматичних ресор, несе на собі елементи вузлів з'єднання візків 3 кузовом вагона, обладнана кронштейнами для гасників коливань, важелів стабілізатора бокового хитання.

Вузол з'єднання кузова вагона 3 візками виконаний 3 опорою кузова на пневматичні ресори центрального підвішування через гумовий пристрій та надресорну балку з передачею поздовжніх навантажень на візки через тумбу-шворінь 3 системою тяг та важелів, а бокове зміщення вагона обмежене комбінованими упорами, розміщеними на центральній рамці, закріпленій на кронштейнах траверси рами візків.

База візка дорівнює 2560 мм, довжина - 3576 20 мм. Візки вписані у габарит 02$\mathrm{BM}$ та мають максимальне розрахункове статичне навантаження від колісної пари на рейки - 176,5 кН (18,0 тс).

Ходові динамічні випробування проходили на ст. Бориспіль ПівденноЗахідної залізниці - ст. Гребінка Південної залізниці. Випробуванням піддавалися пасажирські вагони масою тари 540 кН, вага вагона брутто складала 653 кН.

Метою проведення порівняльних випробувань $\epsilon$ експериментальна перевірка відповідності ходових динамічних якостей руху дослідних вагонів вимогам чинних нормативних документів [3] 3 наступною математичною обробкою та визначенням характеру та закономірностей розподілення діючих на вагон навантажень.

При проведенні ходових динамічних випробувань реєструвались процеси, що характеризують ходові якості вагона під час руху із різними швидкостями на прямих, кривих ділянках колії та стрілочних переводах:

- коефіцієнти вертикальної динаміки для сил, що діють на раму візка;

- коефіцієнти вертикальної динаміки для сил, що діють на елементи кузова;

- горизонтальні (поперечні) сили, що діють на колісні пари;

- прискорення на рівні підлоги кузова вагона;

- динамічні прогини ресорного підвішування.

Радіус кривих при швидкостях 75 та 90 км/год складав відповідно 1100 та 1600 метрів, а при швидкостях 120 та 160 км/год - відповідно 2800 та 2200 метрів.

При проведенні випробувань застосовувались прилади, що реєструють динамічні процеси, перетворювачі та засоби вимірювальної техніки, використовувались відомі методи тензометрії. Для вимірювань та реєстрації динамічних процесів під час проведення ходових динамічних випробувань застосовувався мобільний вимірювальнообчислювальний комплекс вагоналабораторії ДП "УкрНДІВ". 
Реєстрація процесів проводилась датчиками, які встановлювались на елементах конструкції вагона i візків відповідно до затвердженої програмою методики. Масив експериментальної інформації за досліджуваними величинами утворювався шляхом послідовного набору обсягу записів (реалізацій) процесів при різних швидкостях i режимах руху дослідного поїзда на випадкових відрізках залізничної колії.

Зареєстровані на магнітному носії динамічні процеси випробувань вагонів оброблялися програмою обчислення миттєвих значень амплітуд процесу. Записи реалізацій проведені в обох напрямах руху поїзда загальною тривалістю не менше
300 с у кожному діапазоні швидкостей. Частота дискретизації записів динамічних процесів дорівнювала 128 Гц.

Результати первинної обробки свідчать, що дослідні вагони задовольняють вимоги нормативних документів щодо динамічних якостей. Показники коефіцієнтів вертикальної та горизонтальної динаміки для навантаженого і порожнього режимів у всіх дослідних вагонів знаходяться в межах допустимих значень.

На наступному етапі досліджень отримані значення коефіцієнта вертикальної динаміки переводилися у цифрову форму (рис. 2).

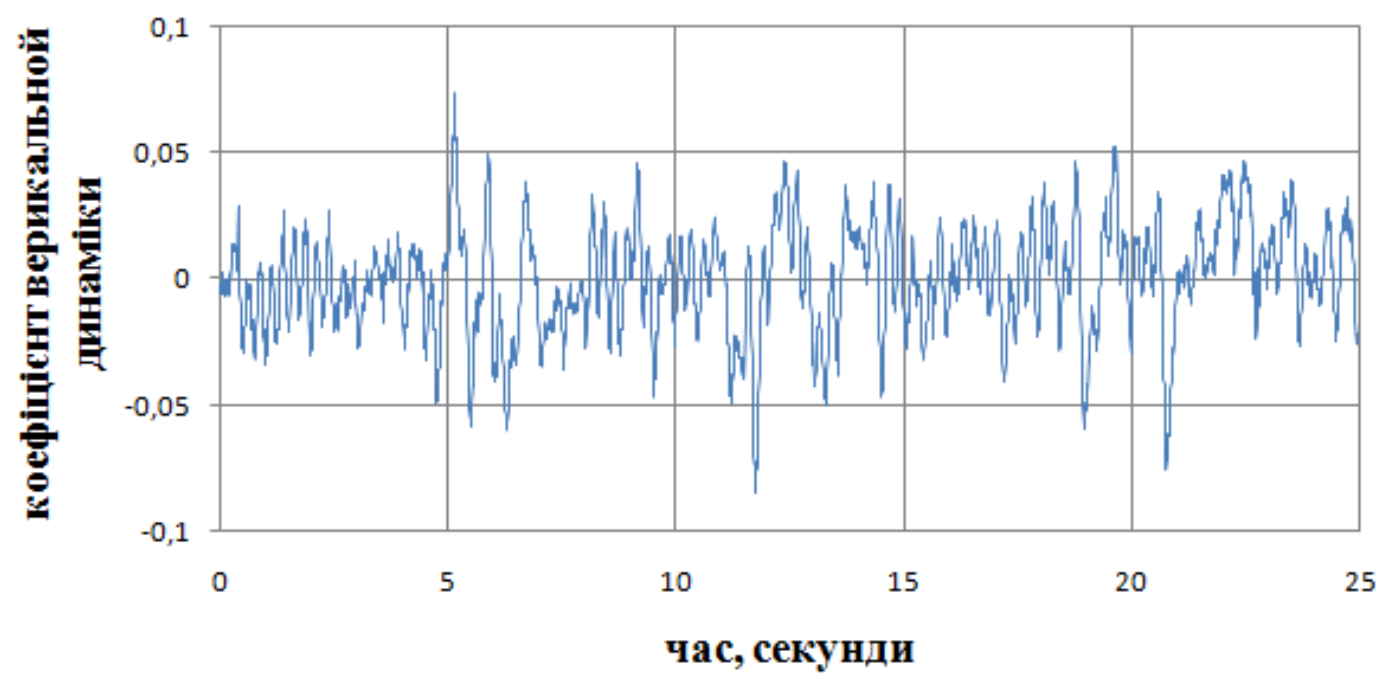

Рис. 2. Залежність зміни коефіцієнта вертикальної динаміки візка на прямій дільниці колії при швидкості 45 км/год

Очевидно, що процес зміни коефіцієнта вертикальної динаміки являє собою випадковий процес 3 синусоїдальною складовою.

Отримані випадкові процеси у подальшому оброблялись відомими методами математичної статистики за допомогою пакета прикладних програм Microsoft Excel. При розрахунках обчислювались моменти 1-4 порядків, що характеризують випадковий процес.
Математичне очікування коефіцієнта вертикальної динаміки та рамних сил обчислювалося як для набігаючої колісної пари візка, так і для другої колісної пари візка. Розрахунки проводилися як на прямих, так і на кривих дільницях колії при швидкостях руху 45, 65, 75, 90, 120, 140 та 160 км/год.

Отримані залежності для математичного очікування коефіцієнта вертикальної динаміки на прямих 
дільницях колії свідчать, що для набігаючої колісної пари він невпинно зростає за лінійним законом відповідно до зростання швидкості руху. Лінійний характер збільшення коефіцієнта вертикальної динаміки характерний і для другої колісної пари, хоч і більш помірний.

Результати розрахунків свідчать, що розподілення коефіцієнта вертикальної динаміки у всіх випадках підкоряється нормальному закону розподілення.

\begin{abstract}
Висновки 3 дослідження i перспективи подалышого розвитку у даному напрямку. Отримані закони розподілення миттєвих значень коефіцієнта вертикальної динаміки для візка. Доведено, що ці значення підкоряються нормальному закону розподілення. Визначені параметри розподілення при різних швидкостях руху. Результати розрахунків можливо використовувати для обчислення розподілення миттєвих динамічних навантажень в елементах рами візка 3 подальшим обчисленням показників безвідмовності.
\end{abstract}

\section{Список літератури}

1. Конструирование и расчёт вагонов [Текст]: учеб. для вузов ж.-д. трансп. / В.В. Лукин, П.С. Анисимов, В.Н. Котуранов и др. - М.: ФГОУ "Учебно-методический центр по образованию на железнодорожном транспорте", 2011. - 688 с.

2. Вершинский, С.В. Анализ динамических характеристик вагонов поезда РТ-200 [Текст] / С.В. Вершинский, В.Е. Усов // Механика наземного транспорта. - К.: Наукова думка, 1977. - С. 33-36.

3. Вагоны грузовые и пассажирские. Методы испытаний на прочность и ходове качества [Текст]: РД 24.050.37-95 - [Введен в действие 96-01-07]. - М.: ГосНИИВ, 1995. 101 с. - (Ведомственный нормативный документ).

Ключові слова: візок, математичне очікування, випадковий процес, коефіцієнт вертикальної динаміки.

\section{Анотації}

Проведено дослідження визначення законів розподілення динамічних навантажень, що діють на візки пасажирських вагонів з пневматичним підвішуванням. Виконано порівняння та встановлені коефіцієнти вертикальної динаміки для сил, що діють на раму візка та елементи кузова, горизонтальні (поперечні) сили, що діють на колісні пари, прискорення на рівні підлоги кузова вагона та динамічні прогини ресорного підвішування.

Проведено исследование законов распределения динамических нагрузок, действующих на тележки пассажирских вагонов с пневматической подвеской. Выполнено сравнение и определены коэффициенты вертикальной динамики для сил, которые действуют на раму тележки.

The above study to determine the laws of distribution of dynamic loads acting on the trolley carriages with pneumatic suspension. Comparison of coefficients and set vertical speakers for the forces acting on the cart frame and body parts, horizontal (lateral) force acting on the wheel pairs, acceleration at underlayment car body and dynamic deflections spring suspension. 